\title{
Znaczenie przyrody w turystyce
}

\author{
Michał Latawiec \\ Wydział Filozofii Chrześcijańskiej, Uniwersytet Kardynała Stefana Wyszyńskiego w Warszawie \\ ul. Wóycickiego 1/3, 01-938 Warszawa \\ m.latawiec@uksw.edu.pl•ORCID 0000-0001-8803-4202
}

\section{Streszczenie}

Najczęstszym powodem uprawiania turystyki jest potrzeba kontaktu z przyrodą. Dzieje się tak szczególnie w czasach współczesnych. Naturalna, dzika przyroda jest wypierana przez rozwój gospodarczy i przemysłowy. Rozwój turystyki przyciąga człowieka do przyrody, ale jednocześnie jest przyczyną wzrastającego dla niej zagrożenia. Okazuje się, że między przyrodą i turystyką zachodzi silna relacja wzajemnego oddziaływania.

Aby podkreślić relacje zachodzące między przyrodą i turystyką, na początku zostanie opisana przyroda jako cel aktywności turystycznych. Następnie ukazane zostaną oddziaływania turysty na przyrodę, a w końcu podjęta zostanie analiza postrzegania przyrody przez człowieka. Taki układ artykułu umożliwi uwrażliwienie na problemy i dylematy wynikające z rozwoju turystyki i jej wpływu na przyrodę.

\section{Słowa kluczowe}

przyroda, turystyka, ochrona przyrody

\section{Wstęp}

Rok 2017 z inicjatywy Zgromadzenia Ogólnego ONZ ogłoszony został Międzynarodowym Rokiem Zrównoważonej Turystyki dla Rozwoju. Oznacza to, że coraz większej rangi w obszarze zrównoważonego rozwoju nabiera turystyka. To przekonanie wyraził m.in. Sekretarz Generalny ONZ stwierdzając, że „potencjał turystyki dla zrównoważonego rozwoju jest ogromny. Jako jeden z największych na świecie sektorów przynoszących zatrudnienie, turystyka pozwala ograniczać ubóstwo i napędza inkluzywny rozwój” (Web-o1). Ważnym elementem powiązanym zarówno z turystyką, jak i ze zrównoważonym rozwojem jest przyroda. To środowisko naturalne jest z jednej strony miejscem, w którym turystyka jest realizowana, a z drugiej zaś jednym z kluczowych filarów zrównoważonego rozwoju.

Zatem przyroda i turystyka są ze sobą wzajemnie powiązane, tzn. dzięki turystyce poznajemy przyrodę, rozumiemy, zdobywamy o niej wiedzę i dzięki temu turystyka pozwala na wzmocnienie działań ochronnych. Poznawanie przyrody poprzez aktywność turystyczną jest podstawowym czynnikiem kształtowania świadomości ekologicznej niezbędnej do skutecznej ochrony przyrody.

\section{Przyroda jako cel}

Turystyka w dużej mierze odbywa się na terenach przyrodniczych. Ma ona postać zarówno przyrody ukształtowanej i zaprojektowanej przez człowieka, jak i obszarów naturalnych i zbliżonych do naturalnych. 
Będą to obszary przyrodniczo cenne. Choć trudno odnaleźć precyzyjną definicję tego określenia, to intuicyjnie zgadzamy się, że będzie to przyroda przedstawiająca wartość dla naszej działalności. Ta wartość będzie odmienna w zależności od perspektywy osoby jej nadającej. Przyroda może być wartościowa ze względów naukowych lub pełnionych funkcji ekologicznych. Dla turysty takie miejsca przyrodniczo cenne będą wartościowe ze względu na możliwości odpoczynku, miejsce nabierania sił lub możliwości kontaktu z przyrodą. Walory takich miejsc są dobrami stworzonymi przez samą naturę lub efektem działalności człowieka. I właśnie takie miejsca wywołują zainteresowanie wśród turystów.

Słusznie J. Mosz zauważa, że „Turystyka zrównoważona traktowana jako model odnoszący się do całej praktyki turystycznej człowieka musi zawierać w sobie przyzwolenie dla ograniczania rozwoju i form turystyki w imię zachowania dóbr wyjątkowych i dla człowieka uniwersalnych" (Mosz 2018: 17). Obszary cenne ze względów przyrodniczych są chronione na podstawie różnych przepisów krajowych i międzynarodowych. W Polsce możemy mówić o ustawie o ochronie przyrody wprowadzającej 10 form ochrony przyrody. Gównie na obszarowych formach ochrony (park narodowy, rezerwat przyrody, park krajobrazowy, obszar chronionego krajobrazu, Natura 200o) realizowana jest turystyka. Choć turystyka nie jest wprost wpisana w definicję tych form - za wyjątkiem obszaru chronionego krajobrazu - to godzenie potrzeb turystów z ochroną przyrody jest dziś konieczne. Interesujące wydaje się, że największe obciążenie turystyczne odczuwane jest w parkach narodowych, a nie w obszarach chronionego krajobrazu. Tworzone plany ochrony tych miejsc wskazują między innymi sposoby ich udostępniania między innymi dla celów turystycznych. „Stosowanie modelu turystyki zrównoważonej na obszarach chronionych musi kierować się racjami racjonalnymi. Zachowanie przyrody dla niej samej nie wydaje się dla współczesnej cywilizacji racją wystarczającą. Człowiek kieruje się raczej przyjemnością, jaką może wywoływać obcowanie z przyrodą. Owa przyjemność jest doznaniem o złożonej strukturze" (Mosz 2018: 23).

Na szczeblu międzynarodowym również mamy wiele konwencji dotyczących tych zagadnień. Dla przykładu, na uwagę zasługuje Konwencja w sprawie ochrony Światowego Dziedzictwa Kulturowego i Naturalnego z 1972r. Konwencja ta traktuje przyrodę jako „dziedzictwo naturalne”. Puszcza Białowieska jest jednym z takich przykładów miejsc podlegających ochronie w ramach konwencji UNESCO. Jest to z jednej strony promocja miejsca i przyciągnięcie turystów, z drugiej zaś - realna troska o zachowanie tych miejsc w obawie przed degradacją.

Najczęściej to przyroda zbliżona do naturalnej jest przestrzenią, na której odbywa się turystyka, bądź jest jej celem. Pierwszym skojarzeniem są parki narodowe. W drugiej kolejności turystyka skupia się na pojedynczych obiektach - często mogą to być pomniki przyrody - wokół których można zbudować zaplecze turystyczne. W Polsce są to m.in. dąb Bartek czy Groty Mechowskie. Warto też wspomnieć, że np. w zachodniej części Teneryfy w miejscowości Icod de los Vinos turystów przyciąga Smocze Drzewo, którego wiek szacuje się na 600 lat.

Teoretycznie zrównoważona turystyka na obszarach chronionych z założenia powinna być już przyjazna dla środowiska, a przynajmniej nie szkodzić przyrodzie. Warto zwrócić uwagę, że według H. Kiryluk „pojęcia turystyki zrównoważonej nie powinno utożsamiać się z określoną formą ruchu turystycznego, lecz należy odnosić się do sposobu organizacji i funkcjonowania gospodarki turystycznej jako całości" (Kiryluk, Borkowska-Niszota 2005: 52). Turystyka taka zatem powinna być dopuszczalna ekologicznie, uzasadniona ekonomicznie i pożądana społecznie.

Choć turystyka nie ma jednej ścisłej i jednoznacznej definicji, to jest kojarzona $\mathrm{z}$ wolnym czasem. Jest to turystyka uprawiana na różne sposoby np.: turystyka piesza, konna, 
rowerowa, kajakowa, wczasy pod gruszą. Niekiedy różne formy turystyki wykluczają się wzajemnie na danym obszarze. Miłośnicy kontemplacji przyrody nie zaznają spokoju w miejscu, gdzie prowadzona jest ekstremalna turystyka motokrosowa. Niemniej jednak, „turystyka to z jednej strony sposób spędzania wolnego czasu, a z drugiej - ważny sektor gospodarki" (Kamieniecka 2015: 23).

W literaturze oraz w dyskusjach medialnych poruszane jest zagadnienie o negatywnym wpływie turystyki na możliwości ochrony przyrody. Zdaje się, że jest to niewłaściwe sformułowanie problemu. Oczywiście z jednej strony, mamy do czynienia z wieloma problemami. Np. zbyt duża liczba turystów przekraczająca pojemność turystyczną danego miejsca. Pojemność ta oznacza „maksymalną liczbę turystów, jaka w tym samym czasie może korzystać z infrastruktury turystycznej, paraturystycznej, komunikacyjnej itd. regionu, nie powodując obniżenia się jakości i zakresu usług oraz produktów turystycznych i nie zakłócając życia społeczno-ekonomicznego w regionie" (Zaręba 2006: 15). Termin ten oznacza również granice odporności środowiska przyrodniczego na działalność turystyczną. Dla przykładu możemy wskazać region Zakopanego. Niestety coraz częściej bijemy różnego typu rekordy (dzienne, weekendowe, sezonowe, roczne) liczby turystów odwiedzających Tatry. W 2018 roku wykupiono ponad 3,6 mln. biletów wstępu na sam obszar Tatrzańskiego Parku Narodowego (TPN). Liczba ta jednak nie uwzględnia mieszkańców gmin przyległych do TPN (Web-02). W tym kontekście interesujące jest porównanie z turystyką na Islandii, której obszar jest wielkokrotnie większy od TPN. „W 2014 roku liczba turystów zagranicznych była trzykrotnie wyższa niż w roku 20oo. (...) W 2016 r. ich liczba wyniosła 1,8 mln wobec 1,3 mln w 2015 r. i 464 tys. w 2009 r." (Bołdak i.in. 2018: 65). Przedstawiciele władz lokalnych już dostrzegają problem związany z gwałtownym wzrostem liczby turystów. „(...) niektóre miejsca zwyczajnie nie są w stanie pomieścić miliona turystów każdego roku. Jeśli zaczniemy wpuszczać do tych miejsc więcej ludzi, stracą one to, co czyni je wyjątkowymi. Jej zdaniem, zarówno krajowy sektor turystyki, jak i sami Islandczycy «muszą uważać, by nie paść ofiarami własnego sukcesu»" (Web-o3).

Z. Witkowski przytacza badania J.M. Liddle dotyczące wpływu turystyki na faunę. Wskazywane są trzy behawioralne elementy zakłóceń odbieranych przez zwierzęta, spowodowane przez turystów. Są to kolejno: 1. Przerywanie spokoju; 2. Zakłócanie (mieszanie się do) dóbr i własności; 3. Naprzykrzanie się. Warto zaznaczyć, że dwa pierwsze typy zakłóceń nie zawsze oddziałują negatywnie na zwierzęta (Witkowski 2007: 188).

Masowość turystyki wiąże się z zadeptywaniem cennej przyrody. W konsekwencji, z utratą wartości tych miejsc. Na odważne i ciekawe rozwiązanie zdecydowały się władze Tajlandii w 2018 r., by na wyspie Ko Phi Phi wprowadzić zakaz wstępu dla turystów do jednej z zatok. To rozwiązanie ma ochronić najbardziej znaną i popularną plażę regionu nazywaną 'niebiańską plażą'. Największym problemem masowej, a często anonimowej turystyki, jest głupota samych turystów. Pojedyncze destrukcyjne zachowania często mają olbrzymi wpływ na przyrodę. Tak stało się np. 21 października 2007 r., gdy grupa turystów utopiła w jednym ze strumieni niespełna dwuletniego niedźwiedzia brunatnego na obszarze TPN.

Z drugiej strony, turystyka daje możliwość wsparcia ekonomicznego na rzecz ochrony odwiedzanych miejsc. Środki finansowe pozostawiane $w$ danych regionach przez turystów są wykorzystywane zarówno na utrzymywanie i poprawę infrastruktury turystycznej, ale także na aktywne działania na rzecz ochrony przyrody. Odpowiedzią na te problemy może być pełne wdrożenie rozwiązań zrównoważonej turystyki: technicznych - zastosowanie odpowiedniej infrastruktury turystycznej; politycznych - wprowadzenie i przestrzeganie limitów pojemności 
turystycznej; ekonomicznych - odpowiedzialny podział środków finansowych.

\section{Wpływ turystyki na przyrodę}

Pewien paradoks odkrywamy w momencie, gdy zaczynamy chronić przyrodę. Otóż, kiedy nadajemy wartość przyrodzie i podejmujemy działania na jej rzecz, musimy liczyć się z zainteresowaniem coraz większej grupy osób chcącej obserwować tę przyrodę. To jest ten moment, w którym przekonujemy innych o wartościach, roli i randze danego obszaru. Chcemy przekonać jak największą liczbę osób do naszego punktu widzenia. Tym samym, chwaląc dany obszar niejako promujemy go, co w konsekwencji inicjuje rozwój turystyki wokół danego miejsca. $\mathrm{Mu}$ simy liczyć się z tym, że coraz więcej osób będzie chciało zobaczyć 'nasze' wyjątkowe obszary. Obecnie trudno sobie wyobrazić wyhamowanie czy też wycofanie turystyki $\mathrm{z}$ miejsc cennych pod względem przyrodniczym. Jak zostało to już wskazane wcześniej, w wielu przypadkach turystyka jest nierozłączna.

Warto przypomnieć poglądy polskich przyrodników tworzących zręby idei ochrony przyrody. Żaden z nich nie sprzeciwiał się turystyce, czy też obecności człowieka w enklawach dzikiej przyrody. Dyskusje dotyczyły jednak sposobu obecności człowieka w przyrodzie. Pionier tej idei Jan Gwalbert Pawlikowski wskazywał, że człowiek w rejonie chronionych terenów mógł obcować z prawdziwą przyrodą. W tych miejscach miał odzyskiwać siły i nabierać nowych, miał również odpoczywać od trudów codzienności i ujemnych skutków postępu cywilizacyjnego. Tę sferę obejmować miała dopiero kształtująca się turystyka. Problemem jednak było ustalenie jej kształtu. Pawlikowski wskazywał na niewłaściwe zachowania części turystów - „wszędzie jak zgraja ogarów ściga ich krzyk i zgiełk filistrów, wszędzie spotykają nienawistne ich ślady, aroganckie podpisy, głupie wierszydła, puszki ze sardynek, tablice pamiątkowe, zatłuszczone gazety i potłuszczone butelki”
(Pawlikowski 1938: 29)1. Podjęto więc dyskusję nad sposobem uprawiania turystyki, głównie górskiej, jak i nad pogodzeniem potrzeb turystów z założeniami ochrony przyrody. J.G. Pawlikowski był zdecydowanym przeciwnikiem znakowania szlaków, budowania ułatwień w spinaczce górskiej oraz budowy kolejek górskich. Jego zdaniem, te elementy zaburzały naturalny charakter przyrody, a w konsekwencji niszczyły te obszary. J. Brunicki dostrzegł, że wraz z turystami pojawiają się pieniądze. Zwracał jednak wyraźnie uwagę, że turystyka może przynieść korzyści jedynie wówczas, gdy zostałby utrzymany charakter przyrody dzikiej. „Ależ Panowie, czy rozwinie się turystyka, choć ułatwimy dostęp w góry, lecz ogołocone z lasów, pozbawione stawów i jezior, wodospadów i widoków skalnych? czy pójdzie kto do lasu głuchego jak grób, a w góry pozbawione wszelkiego naturalnego uroku!" (Brunicki 1911: 135).

O ile w Polsce przedwojennej na szlakach turystycznych pojawiało się niewielu turystów, o tyle w Polsce Ludowej turystyka nabrała cechy masowości. I ta masowość ruchu turystycznego, zdaniem Walerego Goetla, stała się zagrożeniem. Zaczęło występować zjawisko niszczenia roślinności, zaśmiecania, zagłuszania przyrody, bezmyślnej ingerencji w świat zwierząt, itp. Zagrożeniem stała się również grupa ludzi, pragnących ulepszać przyrodę. „Niebezpieczeństwo polega na tym, że i ci «ujarzmiciele» przyrody, którzy mienią się równocześnie jej miłośnikami, zapatrzeni jednostronnie w swój odcinek pracy technicznej, nie zdają sobie sprawy, jakie szkody przynoszą przyrodzie i jej zasobom. Przez to stają się oni czasem szkodliwsi dla przyrody od ludzi, których poza osobistymi interesami nic nie obchodzi" (Goetel 1956: 10).

W. Goetel chciał pogodzić postulaty ochrony przyrody z turystyką, jednak nie wskazał na sposób realizacji tego celu.

$1 \mathrm{~W}$ całej poniższej części cytaty zaczerpnięte z tekstów Pawlikowskiego, Brunickiego, Goetla zostały przytoczone $\mathrm{z}$ zachowaniem oryginalnej pisowni. 
Szukał kompromisu i ukazywał obopólne korzyści. Turystyka na obszarach chronionych może przynieść korzyści ekonomiczne, dzięki którym można podejmować działania ochronne, a także podnosić jakość turystyki. Przykładem takim jest np. dąb Bartek. „Z Gór Świętokrzyskich należy zanotować ciekawy przykład atrakcyjności turystycznej zabytku przyrody. Oto olbrzymi dąb «Bartek» w nadleśnictwie państw. Samosnów, ściągnął sam jeden w ciągu roku około 2.000 turystów, w tym szereg cudzoziemców. Jak to czasem warto wprost z czysto materialnego punktu widzenia chronić przyrodę!" (Goetel 1937: 173).

Konieczność zawarcia kompromisu według Goetla można przedstawić następująco: część terenów udostępnić ludziom, a część zabezpieczyć i ograniczyć ruch turystyczny. „Rozwój turystyki wymaga możliwego udostępniania gór, ochraniarstwo pociąga za sobą konieczność ograniczenia dostępu do nich, oto - głosi się z niektórych stron dwie tezy ze sobą sprzeczne, których równoczesne stosowanie na jednym terenie jest niemożliwe" (Goetel 1934: 141). Nie mogąc tych interesów oddzielić od siebie, należy podjąć próbę ich pogodzenia. Zdaniem Goetla, są one skazane na współżycie ze sobą. „Turysta potrzebuje dla uprawiania turystyki terenów niezniszczonej, pięknej przyrody, zachowanie takiej przyrody może mu dać tylko rozumnie pojęta akcja ochrony przyrody - oto prawda których uzasadnienie szerzy się z życiową siłą w kołach turystów górskich. Prof. J.G. Pawlikowski, duchowy ojciec tatrzańskiego ochroniarstwa, doszedł wszak do swych haseł ochrony przyrody nie przez żadne oderwane od życia piękno-duchostwo, ale przez swe czynne uprawianie taternictwa, w którem osiągnął swego czasu pierwszorzędne wyczyny. Proces wewnętrzny Pawlikowskiego przeżywały i przeżywają setki i tysiące taterników i turystów. I ja też doszedłem do przejęcia się ochroniarstwem przedewszystkiem na drodze uprawiania taternictwa, a nie sposobu wpływu innych czynników, jak o tem świadczą artykuły z mych pierwszych wycieczek"
(Goetel 1934: 141). Goetel stał na stanowisku, że w celu ochrony przyrody należy znakować szlaki turystyczne wprowadzać ułatwienia dla turystów, ale jednocześnie kanalizować ruch turystyczny, aby móc nim zarządzać.

Stefan Kozłowski natomiast proponował turystykę skierować na obszary chronionego krajobrazu. Tworząc tę formę ochrony „szczegółowe projektowanie obszarów chronionego krajobrazu powinno przebiegać $\mathrm{z}$ udziałem trzech zainteresowanych stron: organów planowania regionalnego, czynników ochrony przyrody oraz instytucji odpowiedzialnych za organizację ruchu turystycznego i wypoczynkowego" (Kozłowski 1972: 3). Takie rozwiązanie miało zabezpieczyć interesy i potrzeby zarówno przyrodników, jak i turystów.

\section{Obraz przyrody oczami turysty}

Niezależnie od tego czy przyroda, którą dostrzega turysta jest efektem działalności człowieka, czy też - jest pozostałością naturalnych ekosystemów. Stanowi przestrzeń, na której odbywa się turystyka. To turysta może ją dostrzec podczas swojej aktywności. Człowiek może obserwować zachodzące w niej procesy. Odkrywamy zatem obraz przyrody, który poznaje turysta. Posługując się wizją lasu można zauważyć, w jaki sposób przyrodę widzą turyści. Gdy porównamy las: gospodarczy z naturalnym uchwycimy różnicę. Oba mogą być wartościowe, ale zarejestrujemy innego rodzaju wartości i emocje. W lesie gospodarczym drzewa rosą prosto w równych rzędach zasadzone przez leśników. Jest to las monokulturowy, w którym nie ma miejsca dla drzew powyginanych, chorych, połamanych. $\mathrm{Na}$ takim terenie bioróżnorodność jest ograniczona, a także zubożałe są procesy przyrodnicze. Jest to las wartościowy ze względów ekonomicznych, a być może niesie za sobą także pewien wymiar estetyczny. W przypadku lasu naturalnego mamy zupełnie inne wrażenia. Jest to las, w którym znajdujemy rośliny różnych gatunków, o zmiennej strukturze wiekowej. Drzewa te rosną - z perspektywy odbiorcy - w sposób chaotyczny. 
Często można odnieść wrażenie, że jest to las niedostępny. W tym przypadku możemy mówić o zupełnie innych wartościach odbieranych przez turystów. Jeden z możliwych podziałów wartości może wskazywać z jednej strony na duchowe (piękno, równowaga, wolność, spokój), z drugiej na materialne (bezpieczeństwo, zasoby przyrodnicze, lekarstwa).

Podobnie oceniamy przyrodę kształtowaną w ogrodach i parkach. Ogrody w stylu renesansowym są całkowicie kształtowane przez człowieka, a roślinność całkowicie podporządkowana człowiekowi. Przyroda jest w nich dostosowana do wcześniejszego projektu - rośliny są skrupulatnie wybierane pod względem gatunku, koloru, kształtu, wieku. Często nadaje się jej również odpowiednią symbolikę. Roślinność jest regularnie strzyżona i podlewana. Natomiast parki w stylu romantycznym (angielskim) są zakładane według innego planu. Często warunki naturalne danego miejsca są wykorzystywane do kształtowania przyrody, która ma sprawiać wrażenie dzikiej i chaotycznej. Turysta w takim miejscu ma doświadczać innego rodzaju przeżyć i emocji.

Ważnym czynnikiem pozwalającym dostrzegać przyrodę podczas zrównoważonej turystyki jest czas. To czas decyduje, czy turysta podczas swojej podróży będzie w stanie poznać przyrodę oraz jej mechanizmy. Czas spędzony na łonie natury może wpłynąć na zmianę sposobu postrzegania przyrody. Pojawia się zatem do możliwość poznania przyrody. Jak pisze Antoni Stępień, poznanie ludzkie polega na uzyskaniu informacji o czymś, na uchwyceniu istnienia i własności czegoś. Dzięki zdolności poznania „człowiek przyswaja sobie świat, w którym żyje, rozszerza się o to, co go transcenduje. Potrzeba posiadania ogólnego poglądu na świat, ogólnej wiedzy o świecie, wypływa zarówno z naturalnej ciekawości, jak i z podejmowania narzucających się zagadnień moralnych i praktycznych (Stępień 1989: 9). Poznanie i zdobywanie informacji pozyskanych w przyrodzie prowadzić może do uzyskania wiedzy. W tym kontekście czas, który spędza turysta w przyrodzie jest istotny.

Wielu z pierwszych filozofów - a później także przyrodników - opisujących świat spędzało swój czas na łonie natury. To ten kontakt z przyrodą owocował rozwijaniem wiedzy. Począwszy od Arystotelesa tworzącego pierwszą próbę hierarchicznej klasyfikacji zwierząt i autora opisu ponad 500 ‘gatunków’. Podobnie czynili późniejsi przyrodnicy-podróżnicy. I tak, Alexander von Humboldt „twierdził, że jego badania i wnioski wyciągnięte na ich podstawie mogły być możliwe tylko dzięki dokładnym notowaniom danych uzyskanych z bezpośrednich obserwacji przyrody" (Huxley 2009: 232). Jego podróże stały się inspiracją dla kolejnych osób pragnących zdobyć wiedzę o świecie przyrody. Podobny sposób myślenia o zdobywaniu wiedzy z bezpośredniego kontaktu z przyrodą prezentował Karol Darwin. Jego liczne podróże zaowocowały okazałą wiedzą naukową.

Niektórzy przyrodnicy - jak Wiliam Bartram - zwracali uwagę, że dopiero długotrwałe obserwacje przyrody mogą dać pełny obraz przyrody. Bartram był przekonany, że obserwacje prowadzone „o różnych porach roku w ciągu wielu lat, umożliwiły mu tak głębokie zrozumienie świata natury, w całej jego złożoności” (Huxley 2oo9: 165). Oczywiście jest to prawda, ale turyści nie mają takich warunków czasowych - o ile nie przyjeżdżają systematycznie $\mathrm{w}$ to samo miejsce. Dlatego należy turystom przekazywać wiedzę w jaki sposób przyroda, na którą patrzą ulega przemianom.

Innym zagadnieniem wpływającym na obraz przyrody jest aspekt emocjonalny. J.G. Pawlikowski dowodził, że najlepszym sposobem na poznanie przyrody będzie bezpośrednie przebywanie na jej łonie. Ta forma może być „powiedział pewien filozof, że nadając imię bierzemy w posiadanie. I rzeczywiście to tylko, co możemy nazwać, przestaje nam być obce, staje się nasze. Dziecko, któremu do okna przylatuje jakiś «nieznany» ptaszek, dopóty nie będzie spokojne, póki się nie dowie co to 
za jeden. Jest to «Czyżyk!» - woła z uniesieniem, jakby dawno wiedziało już o tem, a teraz tylko przywołało do pamięci. Z tą chwilą ptaszek dopiero staje się znajomym, wyodrębnia się z pomiędzy mnustwa ptaszków, staje sie kimś. Ale oto za towarzyszem zaczynają przylatywać do oka inne czyżyki. Pośród nich czyżyk zaginął. I znów dziecko nie uspokoi się, póki nie odróżni go po jakiejś odmiance i nie nazwie «Jasiem». Reszta to są tylko inne «czyżyki», chyba, że którenś dostąpi znowu zaszczytu indywidualności, jako «Kubuś» lub «Dziopka»" (Pawlikowski 1938: 16). Bezpośrednie obcowanie z naturą ma być odpowiedzią na skrócenie kontaktu z przyrodą, a także na odwrócenie się człowieka od przyrody.

Dyskusje nad pozytywnym i negatywnym wpływem turystyki na przyrodę i przyrody na rozwój lub wyhamowanie turystyki toczą się również na temat odpowiedzialności człowieka za podejmowane decyzje. „Coraz lepsze poznanie wzajemnych relacji zachodzących w świecie przyrody nakłada na ludzi nowe obowiązki i zwiększa odpowiedzialność za podejmowaną działalność" (Latawiec 2016: 82). Chodzi o takie zarządzanie rozwojem turystyki, by nie zagrażała ona przyrodzie, a także by przyroda mogła się tak rozwijać, żeby można było realizować w sposób nieszkodliwy różne rodzaje turystyki. Myśląc o problematyce odpowiedzialności człowieka za przyrodę nie można pominąć H. Jonasa. Z. Łepko, odczytuje intencje Jonasa następująco: „zróżnicowanych wzorców odpowiedzialności człowieka Jonas nie ogranicza do relacji międzyludzkich, lecz rozciąga je także na relacje człowieka z całą biosferą. Odkąd bowiem «człowiek stał się niebezpieczny nie tylko dla siebie, lecz i dla całej biosfery, spadła na nas swego rodzaju odpowiedzialność metafizyczna, wykraczająca ponad interes własny» (Jonas 1979, 246)" (Łepko 2017:161).

\section{Zakończenie}

Powyższe dociekania pozwalają na sformułowanie następujących wniosków. Po pierwsze, celem turystyki dla zrównoważonego rozwoju powinno być minimalizowanie negatywnych skutków samej turystyki. W konsekwencji możliwe jest dostrzeżenie wielu pozytywnych efektów tak prowadzonej turystyki. Po drugie, rozwój racjonalnie kształtowanej turystyki prowadzi do odkrywania obrazu przyrody. Po trzecie, w momencie uchwycenia wartości przyrody na drodze np. eksploracji turystycznej, możliwa jest zmiana postawy człowieka wobec problemów ochrony środowiska. Ostatnim wnioskiem jest podkreślenie, że w perspektywie humanistycznej istotą turystyki dla zrównoważonego rozwoju w kontekście przyrody jest poznanie elementów przyrodniczych i relacji ich łączących.

\section{Bibliografia}

Bołdak A., Stefanowska A., Niwiński M., 2018, Boom turystyczny $w$ Islandii - wyzwania zrównoważonego rozwoju, Studia Ecologiae et Bioethicae, vol. 16 , no. $2,63-71$.

Brunicki J., 1911, W sprawie ochrony zabytków przyrody, Sylwan: Organ Galicyjskiego Towarzystwa Leśnego 29(3), 132-139.

Goetel W, 1937, O ochronę przyrody gór, Wierchy rocznik poświęcony górom i góralszczyźnie 15, 148-178.

Goetel W., 1934, Rozwój prac nad górskiemi parkami narodowemi, Wierchy rocznik poświęcony górom i góralszczyźnie 12, 140-16o.

Goetel W., 1956, Zagadnienie ochrony zasobów przyrody, Chrońmy Przyrodę Ojczystą 12(5), 3-11.

Huxley R. (red.), 2009, Wielcy przyrodnicy. Od Arystotelesa do Darwina, PWN, Warszawa.

Kamieniecka J., 2015, Różnorodność biologiczna a turystyka, SERIA BROSZUR PRZYRODA OBYWATELE - ROZWÓJ, Instytut na rzecz Ekorozwoju, Warszawa.

Konwencja UNESCO w sprawie ochrony światowego dziedzictwa kulturalnego i naturalnego, Dz.U.76.32.190

Kozłowski S., 1972, Ochrona krajobrazu w Polsce, Wszechświat 1, s. 1-6.

Kiryluk H., Borkowska-Niszota M., 2005, Turystyka zrównoważona, w: Poskrobko B. (red.), „Zarządzanie turystyką na obszarach przyrodniczo cennych”, Wyd. WSE w Białymstoku, Białystok. 
Latawiec M., 2016, Rozpoznawanie granic ingerencji człowieka w środowisko przyrodnicze, Studia Ecologiae et Bioethicae, vol. 14, no. 1, 77-97.

Łepko Z., 2017, Filozoficzne obrazy przyrody ożywionej a idea zrównoważonego rozwoju, w: Sadowski R., Łepko Z. (red.), „Theoria i praxis zrównoważonego rozwoju. 30 lat od ogłoszenia Raportu Brundtland", Towarzystwo Naukowe Franciszka Salezego, Warszawa, 155-168.

Mosz J., 2018, Pragmatyczne $i$ ideowe aspekty turystyki zrównoważonej, Studia Ecologiae et Bioethicae, vol. 16, no. 2, 17-28.

Pawlikowski J.G., 1938, Kultura a natura, w: Pawlikowski J. G. (red.), „O lice Ziemi. Wybór pism”, (red.), wyd. Państwowa Rada Ochrony Przyrody, Warszawa, 3-53.
Stępień A.B., 1989, Wstęp do filozofii, Towarzystwo Naukowe KUL, Lublin.

Witkowski Z., 2007, Wptyw turystyki na ochrone przyrody, w: Grzegorczyk M. (red.), „Integralna ochrona Przyrody", IOP Kraków, 187-189.

Zaręba D., 2006, Ekoturystyka, PWN, Warszawa.

Web-o1: http://www.unic.un.org.pl/unic-activities/ historyczne-porozumienie-w-sprawie-klimatu-zostalo-zawarte/2913, dostęp 2.12.2018.

Web-o2: https://tpn.pl/zwiedzaj/turystyka/statystyka, dostęp 4.01.2019

Web-o3: https://www.forbes.pl/wiadomosci/naplyw-turystow-do-islandii-i-plany-podniesienia-podatkow/cbrmbry dostęp 2.12.2018

\section{The role of nature in tourism}

\section{Abstract}

An important reason for doing tourism is the need to contact with nature. Wild nature is threatened by economic and industrial development. The development of tourism enables people to have more contact with nature, but at the same time is the reason for the growing threat to it. There is a strong interaction between nature and tourism. To emphasize this interaction, at the beginning of the article nature will be described as a destination for tourist activities. Then there will be described how the tourism can impact on nature. Finally, I would like to answer the question, how people perceive the nature. The article will emphasise problems and dilemmas arising from the development of tourism and its impact on nature.

\section{Keywords}

nature, tourism, nature protection 